\title{
The living conditions of prisoners in «Alzhir» camp (by witnesses memories)
}

DOI: $10.31551 / 2410-2725-2019-5-2-163-176$

\section{Kudaibergenova Aizhamal Ibragimovna}

Head of the Historical demography and Assembly of People of Kazakhstandepartment, doctor of historical sciences, associate professor. Almaty, Kazakhstan.E-mail: akudaybergen@mail.ru

\section{Murzakhodzhayev Kuanysh Madievich}

Research fellow Institute of History and ethnology Ch.Ch. Valikhanov, PhD doctoralstudent. Almaty, Kazakhstan. E-mail: kuka_ist@mail.ru

\section{Omarova Gulnar Alimbekovna}

Research fellow Institute of History and ethnology Ch.Ch. Valikhanov, Master of Humanities. Almaty, Kazakhstan. E-mail: gulnara_78@mail.ru

\section{Zhunussova Bota Nadirovna}

Research fellow Institute of History and ethnology Ch.Ch. Valikhanov, Master of Social sciences. Almaty, Kazakhstan. E-mail: botanadirkyzy@gmail.com

\begin{abstract}
The Bolsheviks took all power to their hands after the October revolution. Those, who protested against the new government were persecuted and imprisoned. The liberty of people and freedom of speech were limited by locking up in prisons throughout the territory of the USSR. Such organization included prisons, labor camps, colonies for resettlement and etc.

The horrors of that period have been kept in the minds of people for evermore and will remain as objects of historical memory. Human memory is unique and special. It never loses own meaning.

In this article, authors try to cover the history of the first female camp in Kazakhstan «ALZHIR», according to ex-prisoners evidence.

ALZHIR prisoners were folk enemies and the 1937-1938 red terror victims. They were mothers, wives, sisters, and daughters of those, who were accused of betrayal of Homeland. In a fact it was the color of Nation. The internal life of labor camp has been discovered and researched by authors. They tried to present an inside view of camp inhabitants everyday life.

The contradictory archival documents and ex-prisoners memories have been analyzed and entered into scientific circulation for the first time. The difference in coverage of living conditions and other aspects of «ALZHIR» labor camp's everyday life was shown. The myths about that place have been dispelled. Key words: labor/work camp; GULAG; KARLAG; ALZHIR; memories; women/children destinies; living condition; totalitarian system; repression; legal norms;survive.
\end{abstract}

\section{«Алжир» тұтқын әйелдерінің материалдық-тұрмыстық ахуалы мен қапаста отыру жағдайы» (куәгерлердің естеліктерінен)}

\section{Құдайбергенова Айжамал Ибрагимқызы}

Тарихи демография және Қазақстан халқы Ассамблеясы бөлімінің меңгерушісі, т.ғ.д., профессор. Қазақстан Республикасы, Алматы қ.. E-mail: akudaybergen@mail.ru

\section{Мурзаходжаев Қуаныш Мәдиұлы}

Ш.Ш. Уәлиханов атындағы Тарих және этнология институтының ғылыми қызметкері, PhD докторант. Қазақстан Республикасы, Алматы қ.. E-mail: kuka_ist@mail.ru

\section{Омарова Гүлнар Әлімбекқызы}

Ш.Ш. Уәлиханов атындағы Тарих және этнология институтының ғылыми қызметкері, гуманитарлық ғылымдар магистрі. Қазақстан Республикасы, Алматы қ.. E-mail: gulnara_78@mail.ru

\section{Жүнісова Бота Нәдірқызы}

Ш.Ш. Уәлиханов атындағы Тарих және этнология институтының ғылыми қызметкері, әлеуметтік ғылымдар магистрі. Қазақстан Республикасы, Алматы қ.. E-mail: botanadirkyzy@gmail.com

Аңдатпа. Қазан төңкерісінен кейін большевиктер билікті қолдарына толықтай шоғырландырып, өздеріне қарсы келгендерді, өзгеше ойлайтындарды, жазығы жоқ адамдарды жаппай темір торға тоғыту науқанын бастап жіберген еді. Соған орай бүкіл КСРО территориясында әртүрлі атаулармен бас бостандығын шектейтін орындар көптеп бой көтереді. Оларға түрмелерді, колонияларды, еңбекпен түзету лагерьлерді, қоныс колонияларын, т.б. жатқызуға болады. Бұл 
қасіретті орындар адамдардың санасына өшірілмес жара салып, тарихи жадында мәңгіге сақталып қалды. Адамның жады ерекше зат, ол уақыт өте келе өзінің маңызын жоғалтпайды. Авторлар осы мақалада лагерьлер куәгерлерінің жадында сақталған естеліктерге сүйене отырып, Қазақстан жерінде құрылған алғашқы әйелдер лагері - «АЛЖИР» туралы сөз етіледі. Бұл жерде қызыл террордың 1937-1938 жж. құрығына ілінген ұлт зиялыларының отбасы мүшелері, әйелдері, аналары, қыздары жазықсыз жапа шеккен болатын. Авторлар еңбекпен түзету лагерьлерінің ішкі өміріне үңіліп, сотталушылардың күнделікті өмірінің ішкі көріністерін сипаттауға тырысты. Архивтік құжаттар мен лагерь өмірінің куәгерлерінің естеліктері бір-біріне қарама-қарсы қойылып, алғаш рет талдаудан өтіп, сараланды. Нәтижесінде АЛЖИР еңбекпен түзету лагерінің материалдық-тұрмыстық жағдайына, әйелдердің күнделікті тіршілігіне ресми құжаттар мен естеліктердің өзара қарама-қайшылығы, т.б. мәселелерге ақиқат сәулесі түсірілді. Кілт сөздер: еңбекпен түзету лагері; ГУЛАГ; КАРЛАГ; АЛЖИР; естеліктер; әйелдер/балалар тағдыры; материалдық-тұрмыстық жағдай; тоталитарлық жүйе; қуғын-сүргін; құқықтық нормалар, тірі қалу.

\section{Материально-бытовое положение и условия содержания узниц «Алжира» (воспоминания свидетельниц)}

\section{Кудайбергенова Айжамал Ибрагимовна}

доктор исторических наук, доцент. Институт истории и этнологии им. Ч.Ч. Валиханова. Казахстан, г. Алматы. E-mail: akudaybergen@mail.ru

\section{Мурзаходжаев Куаныш Мадиевич}

Научный сотрудник института Истории и этнологии им. Ч.Ч. Валиханова, РhDдокторант. г. Алматы, Республика Казахстан. E-mail: kuka_ist@mail.ru

\section{Омарова Гульнар Алимбековна}

Научный сотрудник института Истории и этнологии им. Ч.Ч. Валиханова, магистр гуманитарных наук. г. Алматы, Республика Казахстан. E-mail: gulnara_78@mail.ru

\section{Жунусова Бота Надировна}

Научный сотрудник института Истории и этнологии им. Ч.Ч. Валиханова, магистр социальных наук. г. Алматы, Республика Казахстан. E-mail: botanadirkyzy@gmail.com

Аннотация. После Октябрьской революции большевики сосредоточили всю власть в своих руках. Тех, кто протестовал новой власти подвергали преследованиям и лишению свободы. В этой связи, по всей территоррии СССР создавались множество мест, где ограничивалась свобода действий и слова. К подобным учреждениям относятся тюрьмы, колонии, трудовые лагеря, колонии для переселения и т.д. Ужасы связанные с этими местами навсегда остались в сознании людей и сохранятся как объекты исторической памяти. Память человека - особая вещь, и со временем она не теряет своего смысла. В данной статье авторы опираясь на сохранившиеся свидетельства бывших узников лагеря, освещают историю первого женского лагеря «АЛЖИР». Узницами этого учреждения оказались члены семей растрелянных жертв красного терррора 1937-1938 годов: женщины, матери и дочери интеллектуалов нации. Авторы изучили внутреннюю жизнь трудовых исправительных лагерей и попытались представить взгляд изнутри на повседневную жизнь подсудимых. Материалы архивных документов и воспоминания свидетелей лагерной жизни противоречивы и проанализированы в данной статье впервые. На основе сопоставительного анализа официальных документов и воспоминаний узниц, показана разница в освещении материально-бытовых условий и других сторон повседневной жизни в трудовом лагере АЛЖИР. Разрушена завеса мифологичности об этом месте.

Ключевые слова: исправительно-трудовой лагерь, ГУЛАГ; КАРЛАГ; АЛЖИР;воспоминания; судьбы женщин/детей; материально-бытовое положение; тоталитарная система; репрессии; правовые нормы, выживать. 
әОЖ / УДК 94(574).084.6

\section{«Алжир» тұтқын әйелдерінің материалдық-тұрмыстық ахуалы мен қапаста отыру жағдайы» (куәгерлердің естеліктерінен)}

\section{А.И. Құдайбергенова, Қ.М. Мурзаходжаев, Г.Ә. Омарова, Б.Н. Жүнісова}

Кіріспе. XX ғасырдың 30-жылдарындағы сталиндік саяси-қуғын-сүргін саясаты қоғамдағы адам санасына салған «жара» тарих бетінде қатталып, адамзат жадында мәңгілікке қалады. Бұл зобалаң жылдар зұлматы талай ұрпақтың санасына өшпестей із қалдырып кетті. Бұл саясат қазақ халқының да тағдырына барынша әсер етті. Ұлт зиялыларымен қатар, олардың отбасы да аяусыз қудалауға ұшырады. Оның жарқын дәлелі қазақ даласындағы жаппай салынған жазасын еңбекпен түзету лагерлерінің біріне айналған «АЛЖИР» екені даусыз. Әйел мен аналарды жазықсыз қудалап, сәбилерінен күштеп айырған зұлматты бұған дейін бұрын-соңды бастан өткермеген халық едік. Еразаматтармен бірдей саяси қуғын-сүргінге ұшыраған аналарымыз 1937 жылдың зұлматынан сырт қалмады. Жазықсыздан жазықсыз «Отанын сатқандардың Ақмола лагеріне» қамалды. 1930 жылдың ортасынан кейін КСРО аумағында мынадай әйелдер лагері болған: АЛЖИР, Горький қаласынан 40 шақырым қашықтықтағы Темняков лагері, Фрунзе қаласынан (қазіргі Бішкек қаласы) 100 шақырым жердегі Джангир лагері және Потьмадағы Темников лагері (Сәрсембина, 2018). № 00486 бұйрықта «Отанын сатқандардың отбасы мүшелері» атанып, сотталған әйелдердің барлығын Темников лагеріне жөнелту айтылған болатын. Алайда саяси қуғын-сүргіннің кең көлемде жүргізілуінің салдарынан «Отанын сатқандардың» әйелдеріне арналған лагерлер көптеп құрыла бастайды. Өкінішке орай мұрағат құжаттары осындай лагерлерде қанша тұтқын әйелдердің болғаны және олардың немен айналысқандығы туралы жөнді мәлімет бере алмайды. Қазіргі күні «Отанын сатқандардың отбасы мүшелері» атанып, сотталған әйелдер отырған Темников, Сібір, Қарағанды, Томск, Джангир, Нижний Тагил, Сегежск, Колыма, Потьма секілді арнайы лагерлер белгілі болып отыр. Олардың ең ірілері Темников, Сібір, Қарағанды еңбекпен түзету лагерлері болды (Система исправительнотрудовых лагерей в СССР, 1981).

Материалдар мен әдістер. Тақырыпты талдау барысында зерттеушілер материалдар ретінде Ресей Федерациясының Мемлекеттік архивінің құжаттарын, «Мемориал» қоғамының жинақтаған архивтік құжаттарын, АЛЖИР мұражай қызметкерлерінің жинақтаған сотталушы әйелдер анықтамалары мен істерін пайдаланды. Кеңестік биліктің еңбекпен түзету лагерьлеріне қатысты қабылдаған заңдары мен шешімдері, нұсқаулықтарының жинақтары талданып, лагерь тамұғында болған әйелдердің естелік жинақтарымен өзара салыстырылды.

Зерттеу жұмысында деректанудың негізгі үш принципі басшылыққа алынды. Методологиялық негізін жалпы тарих ғылымындағы методтар мен арнайы әдістер қолданылды. Соның ішінде салыстырмалы талдау мен синтез, тарихилық принципі, обьективтілік, жүйелік әдіс, т.б.

Талқылау. Кеңестік ГУЛАГ жүйесінің жұмысын баяндайтын, оның алғашқы құрылуы мен ыдырауына дейінгі тарихы жөнінде жарыққа шыққан еңбектер жетерлік. Мәселен, олардың көп бөлігін архивтік құжаттар жинағы құрайды (Безбородов; Хрусталев, 2004). 7-томдық бұл жинақта ГУЛАГ жүйесінің экономикасы, сотталушылардың саны мен орналасуы, күзет пен күзетшілер, 
т.б. мәселелерге қатысты ІІХК нұсқаулары мен бұйрықтары, статистикалық мәліметтер келтірілген. Ал А.Н. Яковлев атындағы электронды жеке қорда Кеңес өкіметі орнағаннан бастап, лагерлерге қатысты шығарылған заңдар жинақталған (Личный архив А.Н. Яковлева). Сонымен қатар, АЛЖИР лагерінің тауқыметін тартқан, жазықсыз сотталған әйелдердің анықтамалары мен куәгерлерлердің естеліктері де көптеп жарыққа шыққан. Мысалы: «Ұрпақтар ұмытпайды» атты саяси қуғын-сүргін құрбандары балаларының естеліктер жинағы (Ұрпақтар ұмытпайды, 2017); «Узницы АЛЖИРа» (Узницы «АЛЖИРа, 2003); (Жүнісбеков, 2014); екі томдық Алаш ардақтыларының еңбектері мен отбасының естеліктері жинақталған «Алаш-АЛЖИР жинағы (Жүнісбеков, 2011).

Алайда, АЛЖИР лагерінің күнделікті тұрмыс тіршілігі, еңбекпен түзеу лагерлерінің материалдық-тұрмыстық қамтамасыз етілуі, жабдықталуы, т.б. мәселелері көптеген зерттеушілердің назарынан тыс қалып жатады. Себебі, бұл мәселелер бойынша архивтік құжаттар аз, бірқатарына шектеу қойылған. Ал куәгерлердің естеліктерінде мұндай мәліметтер өте аз айтылады (куәгерлер жанына жара салған лагерь күндерін естеріне алғылары келмейді, барлығының берген мәліметтерін топтасақ, бірауыздан айтатыны -, жазықсыз сотталғандығы, лагерьдегі жұмыстың қиындығы, қалай күйеулерінің ұсталғандығы, өздерінің қалай тұтқындалғаны, қай уақытта лагерь құрсауынан босап, ақталғандығы, т.б. Ал әйелдердің лагерьде өткізген 3-8 жыл аралығындағы күнделікті өмірі жайлы жақ ашпайды. Әрине бұл да түсінікті жәйт).

Нәтижелер. 1917 ж. революциядан кейін Кеңестік тоталитарлық жүйе өзінің қауқарына мініп, билік жолында аяусыз зорлық-зомбылықтарға сүйенді. Оның бір дәлелі ретінде қуғын-сүргін қиянаты орын алған жылдары, 1931 жылдан бастап 1954жылдың 1 ақпанына дейінгі кезеңде КСРО-да соттан тыс және сот органдары 3 млн 777 мың адамды ату жазасына соттап, оның 643 мыңына үкім орындалса, ал 2 млн 369 мыңын 25 жылға дейінгі мерзімге түрмелерге қамап, лагерьлерге айдалған делінеді.

Қазақстанға келсек, тарихшы ғалымдарымыздың 1991 жылы жарияланған зертеулерінде 1920-1953 жылдар аралығында саяси қуғын-сүргінге 110 мың адам ұшырады деп есептелінді (Козыбаев, 1991: 9). Кейінгі кезде бұл сан нақтылануда: 118 мың адам сотталған деген мәлімет бар. Олардың 25 мыңына ату жазасы кесілген.

XX ғасырдың 30-40 жылдары КСРО басшылығы Қазақстанды лагерлер еліне айналдыруға әрекет жасады. Сөйтіп ел аумағында Карлаг, Степлаг, Жезлаг лагерлері және т.б. лагерлер бірінен соң бірі ашылды Солардың бірі халық арасында «АЛЖИР» деп аталып кеткен әйелдер лагері қазіргі Астана қаласына жақын маңда орналасқан болатын. Бұл жерге саяси айыптаулармен (негізінен 58-бап бойынша) сотталған әйелдер Кеңес Одағының түкпіртүкпірінен әкелінді. Олардың көбісі елдің белгілі мемлекеттік және қоғамдық қайраткерлерінің әйелдері, аналары, қыздары болатын (Кабульдинов, 2017).

Соның ішінде Отанын сатқандар әйелдерінің Ақмола лагері ерекше назар аудартады. Сотталушы әйелдер арасында «АЛЖИР» аталып кеткен бұл лагер ресми құжаттарда «Р-17» немесе «26-нүкте» деп аталып, қазіргі Астана қаласының маңында орналасқан.

1937 жылдың 3 шілдеде IIXК Батыс Сібір бойынша басқармасының бастығы Сергей Наумович Миронов пен Қазақстан Ішкі істер халық комиссары Лев Борисович Залин бір мезгілде шұғыл құпия тапсырма алады. Онда күзеті күшейтіліп, қатаң тәртіптегі тікенек сыммен және биік дуалмен қоршалған концентрациялық лагерь ұйымдастыруға пәрмен берілген екен. Мұнда қанқұйлы қылмыскер немесе кәнігі ұры емес, нәзік жанды әйелдер - аналар, 
жұбайлар, әпкелер және балалар ұсталуға тиіс болыпты. Олардың бар күнәсі елінің болашағы үшін аянбай еңбек еткен ұлт зиялыларының туысқаны болғандығы ғана.

26-нүкте ҚарЛАГ түрмелер жүйесіндегі бөлімшелердің бірі. 1931 ж. Саратов облысынан кулактарды жер аударған кезде алғашқы арнайы қоныс ретінде пайда болды. Арнайы қонстанушылар оздері екі-үш барак салып алады. Көп ұзамай, бұл жерге Белорусиядан, Қырымнан, Украинадан, Молдавиядан жер аударылған арнайы қоныстанушылар әкелінеді. 1937 ж. арнайы қоныстанушыларды басқа қоныстарға көшіріп, орнына, келесі жылдың басында, қақаған қыста кеңестік номенклатураның басшылық орындарында жұмыс атқарып, «халық жауы» айдарымен жазаға іліккен, сотталған, көпшілігі атылып кеткен біртуар азаматтардың жұбайлары, аналары мен балалары тауарлы вагондармен әкелінді. Қазақстан жері жазықсыз жапа шеккен әйелдердің қанды жасына тұншықты.

1938 ж. құрылған АЛЖИР лагері аз ғана уақыт ішінде жазықсыз сотталушыларға лық толады. Әйелдер мен балалардың ұсталуына 1937 жылғы 15 тамыздағы №00486 Ішкі істерхалық комиссары Н. Ежовтың жедел бұйрығы тікелей әсер етті. Бұйрықта: «Осы бұйрықты алғаннан соң 1936 жылдың 1 тамызынан бастап бірінші және екінші категория бойынша әскери Алқа және әскери трибуналда айыпталған оңшыл-троцкистік тыңшылықдиверсиялық ұйымдар мүшелері, Отанын сатқандар әйелдерін репрессиялауға кірісіңдер» деп ашық айтылды (Көлбаев, 2019). Осы бұйрықтан кейін арнайы лагерлерді құру қажеттілігі туындайды. 1918 жылдан бастап 1953 жылға дейінгі аралықта, яғни 35 жыл бойы түрліше аталған түрмелер мен еңбекпен түзету лагерлері, еңбекпен түзету колониялары кеңес мемлекетінің ажыратылмас бөлігіне айналды.Қазақ даласында да осындай түрмелер, мәжбүрлеп еңбек еткізетін лагерлер санының артқаны белгілі.

Жалпы алғанда, ГУЛАГ жүйесінде 1930-1956 жж. аралығындағы еңбекпен түзеу лагерлері мен колониялардағы сотталған адамдардың саны жөнінде КСРО ІІМ ЕТЛң бас басқармасының төрағасы П.Н. Бакин КСРО бас прокуроры П.И. Кудрявцевке берген есебінде төмендегідей адамдар санының динамикасын көрсетеді: 1938 ж. - 1881570 мың адам, 1939 ж. - 1672438 мың, 1941 ж. - 1929729 мың, 1950 ж. - 2561351 мың, 1953 ж. - 2472247, 1954 ж. 1325003 мың адам отырған.(Безбородов; Хрусталев, 2004: 129).

1934 жылы С.М. Кировты өлтіргеннен кейін сотталғандарға қатаң қарау күшейіп, түрме, ЕТЛ, ЕТК жабық орынға айнала бастайды. 1935 жылғы 27маусымдағы ІІХК-ның № 36354 бұйрығында барлық түрме, колония басшыларына баспасөзге сотталғандар туралы ақпараттың берілмеуі және баспасөзбен байланысты үзу мәселесін күн тәртібіне қою ескертіледі.

Осыншама жазасын өтеушілерді лагерлерге бөліп, оларды күнделікті тұтынатын қарапайым заттармен (сабын, киім-кешек, аяқ киім, құралжабдықтар, т.б.) қамтамасыз ету, күнделікті-материалдық жағдайын жақсарту, мәжбүрлі еңбек ету шараларын ұйымдастыру, т.б. мәселесі өзекті болды. Өйткені, сотталушыларды КСРО-ның экономикасына үлес қосулары үшін, қарапайым адам бармайтын, өмір сүре алмайтын, мүлдем игерілмеген алыс әрі ауа райы қатал аудандарға еңбекке жегіп, пайда алуды көздеген. Бірақ, Кеңес билігінің бұл мақсаты толықтай жүзеге аспады.

ГУЛАГ лагерлерінің барлығына ортақ кемшіліктері болды, олар антисанитария, қарапайым гигиеналық заттардың тапшылығы, мезгілге сай киім-кешекпен жабдықталмауы, т.б. Сөзімізді дәйектейтін болсақ, Соловец аралындағы (УСЛОН) лагерлерінің тұрмыс-тіршілігін зерттеген арнайы 
комиссия қорытындысы бойынша сотталушыларды емдейтін дәрігерлердің болмауы, не кәсіби дәрігер орнына сол сотталушылардың бірі болатыны анықталды. Сонымен қатар үй-жайлардың мүлдем ауа райына икемсіздігі айтылып, ал сотталушыларға киім-кешек жетпегендіктен, олар жұмысқа кейде жалаңаш шығуға мәжбүр болғандығы туралы жазылған (Безбородов; Хрусталев, 2004: 141).

1938 ж. концентрациялы лагерлердегі жазасын өтеушілердің тұрмыстық жағдайын тексерген комиссияның қорытындысы бойынша төмендегі өрескел қателіктер орын алғандығы баяндалады. Мәселен, Байкало-Амур лагеріндегі тұтқындар суық, лас барактарда тұрғандығы, ал адамдарды категориялар бойынша дұрыс орналастырмағандықтан, күші басым сотталушылар әлсіздерге күш көрсетіп, олардың тамағын, киімін тартып алып отырғандығы анықталған. Отырған барлық адамдардың жартысына жуығы биттеп кеткен, тіпті жұмыс істеуге киетін киімдері жоқ жалаңаштар, «санитарлы тұрғыда қауіпті элементтерге айналған», - деп көрсетеді (Безбородов; Хрусталев, 2004: 158). Ал Ухто-Печерский лагерінде жатын үймен тек $50 \%$ ғана жабдықталғандығы, қалғандары қысы-жазы палаткаларда өмір сүріп жатқан болатын. Осы аталған мүшкіл жағдай барлық дерлік лагерлерге ортақ сипат болды.

Жоғарыда аталған қателіктерді ескере отырып, КСРО IIXK №0033 «IIXK колониялары мен еңбекпен түзету лагерлерінде отырған сотталушылардың фризикалық ахуалын жақсарту мен сақтау» жөнінде бұйрық шығарған. Ол бойынша жазасын өтеушілердің тұрмыстық ахуалының нашар болуы себепті олардың еңбек өнімділігі күрт төмендеп кеткендігі айтылған. Соған орай бірнеше шараларды жүзеге асыру тапсырылады. Мысалы, ауа райының қолайсыз күндері таза ауада жұмысқа шығармау керектігі, айына 3 күн міндетті демалыс беру, ол күндері жазасын өтеушілерді мүлдем жұмысқа жекпеу, 8 сағаттық демалыс, т.б. Келесі нұсқаулар назар аудартады: әр адамға баракта пайдалы тұрмыс көлемі 2 шаршы метрден кем болмауы және барактардағы температура 12-14 градустан төмен болмауы анық бұйырылған. Ал 3-ярусты жататын төсектерді толығымен 2-ярусты төсектерге ауыстыру, бөлмелерді үстелдермен, орындықтармен, сөрелермен жабдықтау бұйырылған (Безбородов; Хрусталев, 2004: 217-218). Осы тапсырманың орындалу барысын тексеру нәтижесінде біршама еңбекпен түзету лагерлерінде тапсырма орындалған, Карлаг бойынша әр адамға 1,9 шаршы метр пайдалы аудан бөлінген, 2-ярусты төсектермен - 75\% құрады, 60\% жастық жапқыштармен, 15\% көрпемен жабдықталғандығы жазылған (Безбородов; Хрусталев, 2004: 230-231).

Дегенмен, жоғарыда айтылған нұсқаулықтар тек қағаз жүзінде қала берді. Лагерлік тәртіптің ішкі өмірін көрген бейбақ аналардың естеліктерінде кереғар көріністер баяндалады. Мәселен, Зағипа Тналина, 3 ай Алматы түрмесінде отырған соң АЛЖИРге этаппен жөнелтілген. Ол кезде жалпы 32 барак болған екен. Әр баракта 300-400 адам тұрған. Жастық пен көрпе қамыспен қапталған, барактың ішін қамыспен жылытқан. Қамысты бірнеше шақырым жолда орналасқан қамысты көлшіктен орып әкелген. 800 г. паек норма асқа қол жеткізу үшін тыным таппай қамысты орып, оларды біріктіріп буған. Оны кептіріп, баракты жылытуға пайдаланған. Бірақ одан айтарлықтай жылулық болмаған. «Таңғы алтыдан бастап жұмысқа кірісетінбіз. Адам мен малды тамақтандыруды салыстырса, малдың ішіп-жемі жақсырақ болған», - деп темір тордың арғы жағындағы өмірді жаспен еске алады. АЛЖИР басшылары болса, тамақтандыру жұмысы жақсы жолға қойылған, жеткілікті болған дейді. Ал Сағадат Ташдитова айтуынша, тамақ жетіспеді, ет мүлдем болған жоқ, қант та 
болмаған. Ал Юзипенко естелігінде (АЛЖИР лагерінің надзирателі) күнделікті жұмыс істейтін де, істемейтін де адамға белгіленген сухой паек норма болған. Асханада бүкіл азық-түлік болған, ет те берілген, сүт те берілген дейді. Барлық көкөністер де берілген. Бидайдан жасалған нан болғанын айтып, ақталғысы келгендей (ЦГА, 2-сер. дер. фрильм «АЛЖИР»).

Мәриям Есенгельдина Әлиханованың айтуынша, сотталушылар ішінде әртүрлі топтағы жазасын өтеушілер болған. Еш кінәсі жоқ 58-баппен айыпталған қарапайым әйелдермен қоса адам өлтірушілер, жезөкшелер, ұрылар да бірге отырған. Куәгердің естелігі бойынша, әйелдер күніне 20 сағат жұмыс жасаған (ЦГА, 2-сер. дер. фильм «АЛЖИР»).

Сол жылдары тұтқындау орындарында жазықсыз жазаланған әйелдерді шынымен қылмыс жасаған (адам өлтірген, адам тонаған) әйелдермен бірге қамау үрдіс алған. Түрмелердегі қылмыскерлер әйелдер түрме тілімен «урки» деп аталған. Соколова Нина Иванова өз естелігінде, «...Құлағымнан балалардың, әйелдердің жылаған дауыстары кетпейді. Алайда, түрмелерде рецидивистер «урки» де болды. Оларды түрме өмірі шошындырмады (Абрамов, 2011: 119). «Урки» өздерін еркін әрі озбыр ұстады. Тіпті, өзге әйелдердің жеке заттарын тартып та алатын еді. Олар айдауылдармен дөрекі сөйлесетін. «Уркилер» әйелдердің әдемі киімдерін тартып алып, қарсылық көрсеткендерді ұрып-соғатын еді. Бұл жағдай мен үшін жабайылық, әрі өте қорқынышты болды. Үлкен әйелдер біздерге «бәріне шыдау керек, төзу керек» дейтін. Мәдениетті, оқыған әйелдер өздерін түрмеге қамап, балаларын тартып алғанда «өз халқына жасалған қандай заңсыздық» деп те жылап жүрді. Әйелдердің ешқайсысы өздерінің жесір қалғандығын білмеді де. Әйелдер жеке камералардан өлердей қорқатын. Әйелдердің көпшілігі балалары мен күйеулерін ойлап қана өмір сүрді» (Абрамов, 2011: 122).

Маршал Тухачевскийдің әпкесі Елизавета Николаевна Тухачевская: «Мальтхаузен концлагерінің макетіне АЛЖИР лагері өте ұқсас, тіпті бірдей. Тек крематорий мұржасы ғана жоқ» дейді. 1948 ж. оны әпкелерімен бірге тағы да 8 жылға соттап, Колымаға айдауға жіберген.

Кучумова Ольга Михайловна, 8 жылға сотталған, ТАСС анықтамалық редакциясында референт болып істеген. Күйеуі Лавров Миахил Александрович КСРО мемлекеттік банкінің орталық бухгалтерия басқармасы төрағасының орынбасары болып еңбек еткен. Отанын сатқан опасыздардың отбасы мүшесі ретінде АЛЖИР-ге қамалған. Осы әйелдің біршама толық естеліктері жазықсыз жапа шеккендердің күнделікті тұрмыс-тіршілігін, материалдық қамтамасыз етілуін сипиттайды. Ольга Михайловнаның мемуарынан: «Ұзын бір барак, 300ге жуық әйелдер. Екі-үш жерден әлсіз шырақтар жанып тұр. Ортада сабан кірпіштен жасалған пеш, мұржасы сорайып төбеге дейін созылған. Өзіміз терген қамыс жанып жатыр, ал пештің кептіріліп жатқан біздің шұлықтар мен аяқ-киімдерімізден бос орны жоқ. Себебі таң азанмен суыққа киіп шығып, жұмыс істеуіміз керек», - деп еске алады (Ұрпақтар ұмытпайды, 2017: 394).

Лагерьге келген алғашқы екі қыс айларында байғұс әйелдер ешбір жұмыстарға тартылмай тек өздерін Сарыарқаның қақаған аязында жылумен қамтамасыз етті, жазда өздеріне пана болатын қамыстан барак салды. Осы себепті лагерде жазасын өтеп жатқан әйелдер 200 адамнан бөлініп сапқа тұрып Ақмола лагеріне жақын орналасқан көлге барып күннің суығы мен ыстығына қарамай күнделікті пайдалану үшін қамыс жинады. Айта кету керек бұл жұмыстың өзі жан жақты, әсіресе психологилық және фризикалық тұрғыдан күйзеліске ұшыраған әлсіз әйелдер үшін өте ауыр болды. Қыстың күні қамыс барактарды тек 6-8 градуска дейн ғана жылытатын дейді Алжирде 
жазасын өтеген әйелдер өз естеліктерінде. Бұл әйелдердің көбісі күйеулері, балалары қайда қалғанын білмей жалпы отбасының ойран болғанына қамығып жүрген бейшара әйелдер болатын. Өз жазықсыздығын дәлелдей алмай дәрменсіз күй кешкен. Түрлі этнос өкілдері бола тұрып әр қайсысының өз уақиғасы болса да, оларды ортақ қайғы-мұң біріктірді, біріне бірі қамқор болды. Бастарына төнген қыйындықты қарқынды жұмыс істеу арқылы, жазасыз бола тұра қоғам алдындағы жазаларын адал өтеуге тырысты. Олардың психикасы бұзылып, жады қайғыға толып кетсе де адал жұмысы арқылы ары қарай тіршілігін жалғастырды. Жазықсыз лагерге аттанған әйелдер түрлі мамандық иесі еді, кейбіреуі басшылық қызметер де атқарған мықты білікті мамандар. Уақыт өте келе олар лагер басшылығымен келісіп өздерін өздері ең керектімен қамтамассыз ету үшін кәсіп орын шаруашылық ұйымдастыруды ойластырады. Тұтқын әйел азаматшалар Ақмола лагері аумағында тігін фрабрикасын, кірпіш зауытын құру, электростанция, монша салу қолға алынды. (Кукушкина, 2002: 95-96).

Осы орайда, тігін фабрикасын ұйымдастырған М.Л. Анцис өз естеліктерінде былай дейді: «Бізді лагерге тыққан адамдарды сөйлеспек түгіл, көргіміз келмесе де олар бізден жұмысты ұйымдастыру бойынша әрекет күтті. Карлагтың сол кездегі басшысы Лениннің сөзі былай еді: «Сіздердің толқуларыңыз біз үшін түсінікті, бірақ айтар жаңалығымыз көңілсіз. Сендердің жолдастарын халық жауы ретінде атылға. Балаларың жетімдер үйінде. Сендерден бас тартқан! Совет Үкіметі оларды нағыз Совет азаматы етіп тәрбиелейді. Ал сендер осы далада өз өмірлеріңізді жалғастыру керексіңдер. Сендер адал жұмыс істеуге мәжбүрсіңдер .» осы талқылау екі сағатқа созылып ақыр сонында Анцис және басқа жазасын өтеп жүрген әйелдер ең жақын елдімекеннен 45 шақырым жерде орналасқан Ақмола лагеріне шикізатты жеткізуді мүмкін деп тапқан. Олардың айтуынша 40 градус суықта осы далаға мыңдаған ана мен балаларды жеткізгенде, басқасы да жететіні айтқан». Бұл тұтқындардың соңғы жауабы еді. Осылайша тігін фабрикасын салуға рұқсат алынған болатын. Келесі күні тұтқын әйел азаматтарды лагер басшылығы дайындаған бұйрықпен таныстырады, онда Э. Кетчикті - тігін фрабрикасы ғимаратын салу құрылысының басшылығына, М. Анцисті құрылыс жобасының техникалық басшылығына, Г.И. Руденконі көкөніс базасына, М.И. Синцованы дәнді дақыл өсіру саласына, Шарыгинаны сүт фрермасына басшылыққа, О. матренинаны кірпіш зауытына, К. Дьяткованы мал дәрігері етіп тағайындапты. Сөйтіп жылдарға созылған қарқынды жұмыс басталып кеттеді. Жұмысқа берілген әйелдер аянбай тәулігіне 12 сағаттын немесе одан да көп артығымен жұмыс істегенін естеліктерінде айтады. (Жүнісбеков, 2014: 85-86).

Әйелдер еңбекпен түзету лагерлерінде халық шарушылығын дамытуға көп үлес қосты. Қазақстан лагерлерінде де, ГУЛАГ-та қолданылған мәжбүрлеп еңбек еткізу әдістері кеңінен пайдаланылды. Мысал ретінде келтірер болсақ:

- күндік тапсырманы (норма) орындамағандарға берілетін нан мөлшері қысқартылған;

- атқарылатын жұмыс дені сау және дімкәс, науқас әйелдерге де бірдей болды. Ал, егер де бір күндік жұмыс нормасы орындалмаса 18 сағат, тіпті одан да көп жұмыс жасатқызған. Сотталған аналар лагерде өздеріне жұмсалған шығынды еңбегімен өтеп қана қоймай, сонымен бірге мемлекетке табыс әкелуге де міндетті болды. Айыпталғандарға ана ретінде ғана емес, адам ретінде де қарамай, ауа-райы да ескерілмей, ауыр жұмыстарды жасатқызған (Ділманов, 1999: 44). РСФСР еңбекпен түзету кодексінде «Пища работающим заключенным увеличивается в соответствий с количеством затрачиваемой 
энергий» - деп жазылғанымен, іс жүзінде жағдай басқаша болды. Сондай-ақ, аталған кодексте тұтқындар еңбегінен түскен таза пайданың 12,5 пайызы сотталғандардың тамағына, ал 40 пайызы тұтқындау орындарындағы өндірісті кеңейтуге, ал 12,5 пайызы түрме, лагерь қызметкерлерін сый-ақымен марапаттауға бөлінетіндігі ескертіледі (Собрание кодексов РСФСР, 1928: 723). Түрмелердегі әйелдер жағдайының адам төзгісіз болғандығы туралы мәліметті, біздер тек қана сотталған аналардың естеліктерінен ғана ала аламыз. Себебі, 1925-1938 жылдардағы ЕТЛ, ЕТК және түрме құжаттарында аталған мәселе төңірегінде әңгіме де қозғалмаған. Түрмелерде тұтқындар санының шектен тыс көп болуы және аурулардың көптігі туралы деректерді мұрағаттардан жиі көруге болады (Сәрсембина, 2018). Сонымен қатар айыпкерлердің арызшағымдары да тексеріліп тұрған. Тексеру нәтижесінде түрмелерде басшылар тарапынан сотталғандарға қысым жасалған жағдайлар да кездескен.

Ал Қарлагтың Ақмола бөлімшесінде «Отанын сатқандар» әйелдері лагерінде соғыс кезінде жағымды жағдайдың қалыптасқанын, әйелдер сегіз сағат жұмыс істеп, балаларымен бірге тұрып, барлық медициналық қызмет көрсету салалары болды деп көрсетеді кейбір құжат деректерінде. Ол жерде сондай-ақ лагерьдегі әйелдердің 10 мың га егістік жерге бидай, арпа, тары, сұлы сияқты дәнді дақылдар еккен, ал 210 мың га суармалы жерге картошка, капуста, қызылша, сәбіз, помидор, қияр және пияз көкөністерді өсірген. Сонымен қатар 500 бас сиыр және 500 бас жылқы өсіретін 2 ферма болған. Ауыл шаруашылық жұмысынан бөлек 2000 әйел қызмет ететін тігін фабрикасы мен тоқыма өндірісі жұмыс істеді. Негізінен бұл жұмыстардың барлығын жазасын өтеп жатқан әйелдер атқарды, кейбірінің көп жылдық тәжірибесі бар аналар еді. Атап өтетін болсақ, бас агроном қызметін ауылшаруашылық ғылымдарының кандидаты Е.А. Сенцова, аға зоотехник қызметін Н.C. Савельева, мал дәрігері қызметін К.М. Дедкова, көкөніс өсіруші-агроном, суармалы егістің меңгерушісі А.И. Руденко атқарған. Ал тігін фрабрикасын тәжірибесі мол маман М.Л. Анцис басқарды. Осы фрабриканың құрылуына да, жұмыс жасауына да атсалысып, ұйымдастырушысы да өзі болды. Бұл фрабрика соғыс жылдары майданда жүрген солдаттарды әскери киімдермен қамтамасыз етіп отырды. Негізінен фабрикаға шикізатты Ивановадан, Тейковадағы тігін фрабрикасынан, Барнаул мен Ташкенттегі комбинаттардан алды. Фабрикада жұмыс істеп жүрген әйелдер: «Бәрі майдан үшін, бәрі жеңіс үшін» деген ұранмен тоқтаусыз жұмыс атқарған. Сөйтіп олар 1942 жылы 1 млн рубльге дейін табыс алып келген ${ }^{1}$.

«АЛЖИР»-дегі ауыр жағдай туралы Мария Даниленко: «Біздер 25, 35, 50 градус салқындық пен 50 градус ыстықта да жұмыс жасадық. Бір жаз ішінде әйелдер 18 құрылыс обьектілерін салдық деп өз естелігінде жазады...» (Грибанова и др., 2002: 82).

Осы аталған лагерьде жазасын өтеген Уәзипа Майжолова-Күленованың естелігіне мән берсек: «Лагерьде таңғы сағат төрттен кешкі сағат алтыға дейін үзіліссіз жұмыс жасайтынбыз. Ет дегенді көрмейміз. Жұмыс басына түсте бір булочка мен шәй алып келеді. Орыс, грузин, армян, түркі әйелдері барлығымыз бір кісіден туғандай бір-бірімізге жанымыз ашып тұратын. Бірде мен, Ақмоланың боранды қысты күндерінде, лагерьдің шығыс жағындағы қамыс көлге түсіп кеттім. Әрең дегенде шықтым. Үсті-басымның бәрі мұз болып қатып, денеме киімдерім жабысып қалған. Күзетшіге баракқа барайын десем, қашып кетеді деп жібермеді. Содан кешке келіп, барактағы әйелдер денемдегі

\footnotetext{
${ }^{1}$ Астана қаласының Мемлекеттік архиві (АҚМА) 370-қ., 1-т., 52-іс., 3-4-пп.; 7-п
} 
жабысып қалған киімдерімді жібітіп, мені босатып алды. Сол оқиғадан кейін қазір менің тырнақтарымның бәрі аппақ цемент сияқты опырылып түсіп жатады (Грибанова и др., 2002: 170)» - деп, өз естелігінде лагерьдегі әйелдердің ауыр жағдайын көрсетеді.

Сонымен қатар, Зағипа Тінәлина өз естелігінде лагерьдегі әйелдердің өмірі туралы былай деп айтады: «...Қатар-қатар барақтар, адам тұратын жайдан гөрі мал немесе ит ұстайтын қораға немесе колхоздың темір-терсек сақтайтын қамбасына ұқсайды. Іші үш қатар нар (бөстекше), ертеңгісін және кешкісін сапқа тұрғызып қойып тексеру, одан айдауылмен итін өршелендіре дедектетіп қара жұмысқа апарады, алып қайтады. Ауыр жұмыстан, аштықтан әлсіреп сүйретіле түннің бір уағында бөстекшелерімізге құлаймыз. Қыста қақап (жылытылмайтын болғандықтан), жазда монша жаққандай пысынап, керегелерінен пар тамшылап, тұншықтырып, алқымды буып, тынысты тарылтатын қапырық сасық үйімізге жолшыбай құлап-сүрініп, итке таланбай аман жеткенге шүкір етеміз. Бір баракта үш жүзге дейін адам тұрамыз... Құлдық дәуірдегі құлақ кесті құлдардың өмірі бізден көш ілгері шығар-ау. Бәрінен қиыны-өнебойы аш құрсақ, жадаумыз. Мен мал бақтым. Күзде қамыс орамыз, белуардан мұздай су кеше, орақпен қамыс орып баулаймыз. Норма-140 бау, күніге. Орындасаң-700 грамм нан аласың. Орындамасаң... адамда жалғыз-ақ арман болады екен: нанға тою! Күздің қара суығында үсті-басымыз суға малшына жататын орынға ораламыз. Таң сәріде қамысқа қайта дірдектеп кетеміз...» (Дәуренбекова, 1993). Мұндай адам төзгісіз жағдайға шыдай алмай өліп кеткендер көп болған. Оларды, яғни өлгендерді түнделетіп арбаға тиеп, қазылған шұңқырларға апарып көміп тастап отырған. Жерге тапсырудың хайуаннан айырмашылығы өлген кісінің башпайына тақтайша байлап, оған нөмірлеп, марқұмның анықтамасы қысқаша жазылған белгімен жерлеген.

Лагерьдің азапты өмірін 1938-жылдан 1955-жылға дейін басынан өткерген Күләндам Қожанованың естелігіне мән берсек: «...Көктемнің жанға жайлы ертеңгі шағы болатын. Лагердің қызметкерлері бізді ауланың ішіне иіріп қойып: Бүкіл жұртшылық Отанымыздың күш-қуатын, хал-ахуалын арттыру жолында бір кісідей ат салысулы. Күні-түні ізденіс, талпыныс. Ал, сендер ше? Рахат! Жағаларыңыз жайлауда, жайбарақат өмір сүріп жатырсыздар. Тамақ үкіметтен! Өңшең әзір асқа тік қасықтар - деп тілдеп-тілдеп алды да, бұдан былай жағдайдың өзгеретіндігін, топ-топқа бөлініп, жұмыс істейтінімізді мәлімдеді...» (Дәуренбекова, 1993).

Сондай-ақ тұтқын аналардың мерекелерді атап өтуге құқы болмаған. Себебі, олар «азаматша» деген құқықтан айырылған болатын.

Ақмоладағы «Отанын сатқандар» әйелдерінің лагері ашылған уақыттан, яғни 1938 жылдың 6 қаңтарынан бастап әйелдер тиелген алғашқы вагон келе бастайды. Олардың ішінде 1 жастан 3 жасқа дейінгі балалы әйелдер бар еді. Лагердегі 2 жасқа дейінгі нәрестелер «балалар комбинатында» ұсталған. Ал баласы төрт жасқа толған кезде оларды Осакаров балалар үйіне жіберіп отырды (Тасымбеков, 1993: 201).

Түрмеде, лагерьде туылған балалар «лагерь балалары» деп аталған. Ал, еңбекпен түзету колониясы мен лагерлерде туылған сәбилерге арнап арнайы балалар бөлмесін ұйымдастыру 1934-жылы айтылған еді. Аналарды балаларын тамақтандыруға конвоймен әкеліп, әкететін болған. Лагерлердегі баласы бар немесе аяғы ауыр әйелдер зона тілімен «машка» деп аталған. «Заключенные женщины, начиная с пятого месяца беременности, не подлежат высылке на работу вне места заключения без их на то согласия»-деп РСФСР 
еңбекпен түзету кодексінде жазылғанымен іс жүзінде жағдай басқаша болды (Собрание кодексов РСФСР, 1993:15).

Лагердегі ауыр жағдай (бөлменің салқындығы, тамақтың жетіспеуі, аналардың ауыр еңбекпен айналысуы және т.б.) сәбилерге қалай әсер еткендігін айтпай-ақ түсінуге болады. Тұтқын өмірін бастан кешірген аналардың естелігінде осы жағдай жиі айтылады. Жак Россиидің айтуынша, жазасын өтеп шыққаннан кейін де аналардың балаларын іздеп, тауып алуы өте қиындықпен жүзеге асқан (Росси, 1991: 235). Лагерден 3-4 жастағы балаларды сәбилер үйіне жөнелту нағыз әскери қимыл ретінде жүргізілген. Сәбилерді анасынан тартып алу түнгі уақытта іске асырылған. Лагерде болған әйелдер өз естеліктерінде жаны күйзелген аналардың балаларынан айырылған сәттегі жан азабын (айдауылдармен төбелесу, тікенек сымдарға, қабырғаға бастарын соғу және т.б.), тіпті кейбір әйелдердің жынданып та кеткендігін қинала айтады (Тасымбеков, 1993: 49). Осындай оқиғаны мысал ретінде айта кетсек, Галина Степанова-Ключникованың естелігінде: «Вераны ұстауға келген ІІХК қызметкерлері өзінің және ұлының киімдерін жинауды бұйырады. Сөйтіп ол екі чемоданға өзінің және баласының киімдерін салып жинайды. Түрмеге барған кезде анасы мен баласын айырып, ұлын балалар үйіне жібереді. Кейін ол чемоданды ашып қараса баласының киімі салынған екен, яғни чемодандарын ауыстырып алған. Екі жылдан кейін хат жазысуға рұқсат ету басталған кезде Вера ұлын іздейді. Ол ұлының қайтыс болғаны туралы хабарлама алады. Қайғыдан қан жұтқан ана күнде чемоданды ашып баласының киімдерін қолына ұстап баласымен сөйлескен сияқты отырады екен, есінен адасып, жынданып кеткен екен». (Жүнісбеков, 2011: 254). Түрмелер мен ЕТЛ-де аяғы ауыр әйелдердің жағдайларына ешқандай мән берілмегендігін мұрағат құжаттарды да дәлелдейді ${ }^{2}$.

Ал ресми билік өкілдерінің көзқарастары мүлдем басқаша болған. Олар отанын сатқан опасыздардың отбасы мүшелеріне жемтікке шүйліккен жыртқыш аңдай озбырлық көрсетіп, оны қалыпты жағдай ретінде сипаттайды. Сөзімізді дәйектейтін болсақ, Қарлаг архипелагының бөлімшелерінде бақылаушы (надзиратель) болып жұмыс атқарған М.Т. Юзипенконың ісі, естелік-жазбасы табылды. Астана қалалық архивінде лагерь тарихына байланысты №370 нөмірмен сақталған М.Т. Юзипенконың (1904-1994 жж.). жеке қорында оның өз әрекетін, АЛЖИРдегі қатал тәртіпті жұмсартып, ақтап жазған естелік-хаттары сақталған.

Естеліктегі Қарағанды лагерінің, соның ішінде Ақмола бөлімшесінің жұмысы және лагерьге тоғытылған әйелдер мен лагерь өмірі жайлы мәліметтер бақылаушының көзқарасы тұрғысында жазылған. Айта кету керек, АЛЖИР тарихына қатысты осы күнге дейінгі жарияланған еңбектерде бұл құжат мәліметтері пайдаланылмаған. Сондықтан бұл құжатты біз алғаш рет ғылыми айналымға тартып отырмыз десек болады (Юзипенко, 52 іс.). Украинаның Черкасск облысы, Писаревка селосында туылып, әкесімен бірге 1903 ж. солтүстік Қазақстанға қоныстанған Юзипенко Михаил Терентьевич өзінің жазбасын 1921-1923 жж. Поволжьенің ашығып жатқан халқына, питерліктерге арнап Солтүстік Қазақстаннан астық жинаған азық-түлік отрядында болғанынан бастайды. (Бұл жылдардың Қазақстанды да ашаршылық жайлаған жылдар екенін ескерейік - автор). Орта Азиядағы, Бұхарадағы басмашылармен күреске кавалерист қатарында қатысқан ол өзінің жүріп өткен өмір жолын еске түсіреді. 1931 жылдан бастап Қарағанды қалалық атқару кеңесінде, партиялық қызметтерде болған Юзипенко 1934 жылдан бастап Қарағанды еңбекпен

${ }^{2}$ Қазақстан Республикасы орталық мемлекеттік архиві (ҚРОММ) 1380-қ., 2-т., 210-іс. 25-п 
түзеу лагерінде бақылаушы қызметін атқарып, 1939 жылдан Қарлагтың 26нүктесінде, Ақмола бөлімшесінде (АЛЖИР-де) әкімшілік-шарушылық бөлімінің бастығы болып қызмет атқарады. 1941-1943 жылдары «АЛЖИР», яғни «Отанын сатқандар» әйелдерінің Ақмола лагерінің бастығының орынбасары болып қызмет атқарады ${ }^{3}$. Қорға автор естеліктерін 1989, 1991, 1992, 1994 жылдары өткізген. Қордың алғы сөзінде М.Т. Юзипенко «1934 жылдың ақпанынан 1948 жылдың наурызына дейін Қазақ КСР ІІХК - ІІМ жүйесінде қызмет еткен, оның ішінде, яғни «26 нүкте», «АЛЖИР» деп аталған Қарлагтың Ақмола лагерінің бастығының орынбасары болды» делінген.

Бұл құжат түрме қызметкерлерінің түрмедегі қатал тәртіпті қалыпты жағдай ретінде қабылдағанына куә деуге болады. Өз міндетін адал атқардым деп есептеген М. Юзипенко Қарлаг Ақмола бөлімшесінің қалыптасуы туралы жазбаларында «Отанын сатқандар» әйелдер лагерінде жағымды жағдайдың қалыптасқанын, әйелдер сегіз сағат жұмыс істеп, балаларымен бірге тұрып, барлық медициналық қызмет көрсету салаларының көмегін пайдаланғанын айтады. Құжат АЛЖИРге тоғытылған әйелдердің айналысқан шаруашылықтарынан хабардар етеді. Ол лагерьдегі әйелдердің 10 мың га егістік жерге бидай, арпа, тары, сұлы сияқты дәнді дақылдар еккенін, 210 мың га суармалы жерге картошка, капуста, қызылша, сәбіз, помидор, қияр және пияз көкөністерді өсіргенін айтады. Лагерьде, сонымен қатар, 500 бас сиыр және 500 бас жылқы өсіретін 2 ферма болған. Ауыл шаруашылық жұмысынан бөлек 2000 әйел қызмет ететін тігін фрабрикасы мен тоқыма өндірісінде жұмыс істеді. Бұл жұмыстардың барлығын жазасын өтеп жатқан әйелдер атқарды, кейбірінің көп жылдық тәжірибесі бар аналар еді. Атап өтетін болсақ, бас агроном қызметін ауылшаруашылық ғылымдарының кандидаты Е.А. Сенцова, аға зоотехник қызметін Н.С. Савельева, мал дәрігері қызметін К.М. Дедкова, көкөніс өсіруші-агроном, суармалы егістің меңгерушісі А.И. Руденко атқарды. Ал тігін фрабрикасын тәжірибесі мол маман М.Л. Анцис басқарды. Осы фабриканың құрылуына да, жұмыс жасауына да атсалысып, ұйымдастырушысы да өзі болды. Бұл фрабрика соғыс жылдары майданда жүрген солдаттарды әскери киімдермен қамтамасыз етіп отырды. Негізінен фрабрикаға шикізатты Ивановадан, Тейковадағы тігін фрабрикасынан, Барнаул мен Ташкенттегі комбинаттардан алды. Фабрикада жұмыс істеп жүрген әйелдер: «Бәрі майдан үшін, бәрі жеңіс үшін» деген ұранмен тоқтаусыз 3 ауысыммен жұмыс атқарған. Сөйтіп олар 1942 жылы 1 млн рубльге дейін табыс алып келді - деп жазады М.Т. Юзипенко ${ }^{4}$.

Ол «Свидетельствую как это было (К истории Карлага)» атты құжатта лагерді тіпті одан әрмен керемет етіп көрсетеді: «Қарлагты тұтқындар орны емес, курорт болды деп айта аламын ба? Басқа лагерлермен салыстырғанда - иə!» - деп жазған ${ }^{5}$. М.Т. Юзипенконың жазған естеліктерінен Қарлагтың тарихы туралы материалдарды ала алатынымызды жоққа шығармаймыз, әсіресе мекеме басшылары, шаруашылық жағдайы мен экономикалық әлеуетіне қатысты мәліметтер кездеседі.

1937-1953 жылдар аралығында АЛЖИР-де болған әйелдердің саны туралы деректер әртүрлі. Бір жерде 7,5 мың, екінші мәліметте 18 мың, үшінші ақпарат көзінде 21 мың әйел түзету лагерінен өткені көрсетіледі. АЛЖИР мемориалды кешенінің қызметкерлері мен зерттеушілер еңбегінің арқасында қазір 7,5 мың әйелдің аты-жөні анықталды. Қалған әйелдердің есімі әлі белгісіз.

\footnotetext{
${ }^{3}$ АҚМА, 1-16-пп.; 1-8-пп; 1-24-пп

${ }^{4}$ АҚМА, 3-4-пп.; 7-п

${ }^{5}$ АҚMА, 13-ח
} 
Қорытынды. Кеңестік тоталитарлық қоғамның адам санасына салған зардаптары әлі күнге дейін жаңғыруда. Сталиндік жазалау саясаты кезінде қазақ халқының ерте заманнан бері сақталып келе жатқан әйелдердің қоғамдық дамудағы орны мен рөліне берілген бағасы мен соған сәйкес келетін қарымқатынастары аяқ асты болды.

Қорыта келгенде, Ақмоладағы «Отанын сатқандар» лагерінде болған әйелдер тағдырын зерттеу, олардың адам төзгісіз жағдайда өмір сүргенін олардың естелік құжаттары дәлелдейді. Себебі, архив қойнауларынан табылған, лагерлерге тоғытылған әйелдерге қатысты ресми құжаттар әйелдерді тұтқындау себептерін қылмысы үшін дәлелді етіп, ал жүкті әйелдердің жағдайы, бала тууы мен бала күтіміне қатысты шараларды адамгершілік принциптерге лайықты етіп көрсетеді. Ресми құжаттарда жазаланған әйелдердің жұмыстан шығарылу себебі «өз еркімен босады» деп тіркелген. Нақты айтқанда ресми құжаттар лагерлердегі тамұқтық жағдайларды обьективті баяндай алмайды.

Архив қорларынан табылған ресми құжаттарды куәгерлер естеліктерімен саралай отырып сол кездегі тарихи ақиқатты ашу зерттеушілер үшін жауапкершілікті іс екендігін айтып өткен орынды. Адам төзгісіз фризикалық және психологиялық қысымнан бейбақ аналар қалайша аман қалды деген сауалға бір ғана жауап бар. Оны Нығмет Сырғабековтың жары Бибіжамал Сырғабекова, АЛЖИР лагерінің тамұғынан аман қалғанын таңдана еске ала отырып сөз етеді.«Бізді - балаларымызды көру үшін, оларды тауып, аяққа тұрғызу, бір құшаққа басу арманы ғана лагер ажалынан аман алып қалды», деген сөзі барша жазықсыз әйелдерге ортақ болғаны анық.

\section{Әдебиеттер тізімі / Список литературы}

1. Абрамов, 2011 - Абрамов Д. Места заключения и репрессированные. Алматы: Глобус, 2001. 142 с.

2. Безбородов; Хрусталев, 2004 - История сталинского Гулага. Конец 1920-х - первая половина 1950-х годов: Собрание документов в 7-ми томах / Отв. ред. А.Б. Безбородов, В.М. Хрусталев. М.: «Российская политическая энциклопедия» РОССПЭН, 2004.

3. Грибанова и др., 2002 - Страницы трагических судеб / Сост. Е.М. Грибанова, А.С. Зулкашева и др. Сборник воспоминаний жертв политических репрессии в 1920-1950 гг. Алматы: Жеті Жарғы, 2002. 448 c.

4. Дәуренбекова, 1993 - Алғашқы қарлығаштар / Құраст. Дәуренбекова Д. Алматы: Қазақстан, 1993. 208 б.

5. Ділманов, 1999 - Ділманов С. Қарағанды лагеріндегі тұтқындар // Ақиқат. 1999. №12. 41-47 бб.

6. Жүнісбеков, 2014 - ALJIR. Qorqinisti tustey... Kak strashnyi son... Estelikter. Vospominaniya / Бac ред. Жүнісбеков Б. Астана, 2014. 364 б.

7. Жүнісбеков, 2011 - «АЛАШ-АЛЖИР / ALASH-ALZHIR» АЛЖИР. I-II Том. Астана: Сарыарқа, 2011.

8. Кабульдинов, 2017 - Кабульдинов 3.Е. АЛЖИР: Лагерь насилия. 25.11.2017 [Электронный pecypc] / URL: http://mysl.kazgazeta.kz/?p=10484 (кіру уақыты 30.05.2019).

9. Козыбаев, 1991 - Козыбаев М.К. Демографические исследования в Казахстане: итоги и перспективы // Вестник АН Каз ССР. 1991. №11. С. 7-13.

10. Көлбаев, 2019 - Тілеу Көлбаев «Алжирдегі» жазықсыз арулар. 25.05.2011 [электронды pecypc] / URL:http://anatili.kazgazeta.kz/?p=6542 (кіру уақыты 30.05.2019)

11. Кукушкина, 2002 - Кукушкина А.Р. Акмолинский лагерь жен «изменников родины»: история и судьбы /МОН РК,Каз.фин.-экон.ун-т. Караганда, 2002. 184с.

12. Личный архив А.Н. Яковлева - Личный архив А.Н. Яковлева [электронный ресурc] / URL: http://www.alexanderyakovlev.org. (кіру уақыты 30.05.2019).

13. Росси, 1991 - Жак Росси. Справочник по ГУЛАГУ. М.: Просвет, 1991. Ч.1. 548 с.

14. Сәрсембина, 2018 - Сәрсембина Қ.Қ. Еңбекпен түзету лагерьлері мен түрмелердегі әйелдер жағдайы (Сталиндік саяси-қуғын-сүргін жылдарындағы) // Edu.e-history. кz. электрондық журнал.2018. №4. (16).

15. Система исправительно-трудовых лагерей в СССР, 1981 - Система исправительнотрудовых лагерей в СССР 1923-1960: Справочник. М., 1981. 479 с. 
16. Собрание кодексов РСФСР, 1928 - Собрание кодексов РСФСР редакции 1926 г. М.: Юр. изд. НКЮ РСФСР, 1928. 1183 с.

17. Тасымбеков, 1993 - Тасымбеков А. Жан дауысы. АЛЖИР архипелагы. Алматы: Жазушы, 1993.223 б.

18. Узницы «АЛЖИРа, 2003 - Узницы «АЛЖИРа». Список женщин - заключенных Акмолинского и других отделений Карлага. М.: Звенья, 2003. 567 с.

19. Ұрпақтар ұмытпайды, 2017 - «Ұрпақтар ұмытпайды» = «Помнят Потомки» = «The descendants remember». Семей, 2017. 514 б.

20. ЦГА, 2-сер. дер. фрильм «АЛЖИР» - Центральный Государственный архив кинофотодокументов и звукозаписи Республики Казахстан

\section{References}

Abramov, 2011 - Abramov D. Mesta zaklyucheniya i repressirovannye. [Places of detention and repressed] Almaty: Globus, 2001. 142 s. (in Rus)

Bezborodov; Hrustalev, 2004 - Istoriya stalinskogo Gulaga. Konec 1920-h - pervaya polovina 1950-h godov: Sobranie dokumentov v 7-mi tomah [History of Stalin's Gulag. Late 1920s - first half of 1950s: Collection of documents in 7 volumes] / Otv. red. A.B. Bezborodov, V.M. Hrustalev. M.: «Rossiyskaya politicheskaya enciklopediya» ROSSPEN, 2004. (in Rus)

Gribanova i dr., 2002 - Stranicy tragicheskih sudeb [Pages of tragic fates] / Sost. E.M. Gribanova, A.S. Zulkasheva i dr. Sbornik vospominaniy zhertv politicheskih repressii v 1920-1950 gg. Almaty: Zheti Zharfy, 2002. 448 s. (in Rus)

Dəurenbekova, 1993 - Algashky karlygashtar [The first swallows] / Kyrast. Daurenbekova D. Almaty: Kazakstan, 1993. 208 b.

Dilmanov, 1999 - Dilmanov S. Karagandy lagerindegi tytkyndar [Prisoners of Karaganda camp] // Akikat. 1999. №12. 41-47 bb.

Zhunisbekov, 2014 - ALJIR. Qorqinisti tustey... Kak strashnyi son... Estelikter. Vospominaniya [Like a bad dream, memories] / Bas red. Zhunisbekov B. Astana, 2014. 364 b.

Zhunisbekov, 2011 - «ALASh-ALZhIR / ALASH-ALZHIR» ALZhIR. I-II Tom. Astana: Saryarka, 2011.

Kabuldinov, 2017 - Kabuldinov Z.E. ALZhIR: Lager nasiliya. [ALZHIR: the Camp of violence] 25.11.2017 [Elektronnyy resurs] / URL: http://mysl.kazgazeta.kz/?p=10484 (kiru иақуty 30.05.2019). (in Rus)

Kozybaev, 1991 - Kozybaev M.K. Demograficheskie issledovaniya v Kazahstane: itogi i perspektivy [Demographic research in Kazakhstan: results and prospects] // Vestnik AN Kaz SSR. 1991. №11. S. 7-13. (in Rus)

Kolbaev, 2019 - Tileu Kolbaev «Alzhirdegi» zhazyksyz arular. [An innocent women of ALZHIR] 25.05.2011 [elektrondy resurs] / URL: http://anatili.kazgazeta.kz/?p=6542 (kiru uakyty 30.05.2019)

Kukushkina, 2002 - Kukushkina A.R. Akmolinskij lager zhen «izmennikov rodiny»: istoriya i sudby [Akmola camp of wives of "traitors of the Motherland": history and destiny] / MON RK, Kaz.fin.ekon.un-t. Karaganda, 2002. 184 s.(in Rus)

Lichnyy arhiv A.N. Yakovleva - Lichnyy arhiv A.N. Yakovleva [Personal archive of A.N. Yakovlev] [elektronnyy resurs] / URL: http://www.alexanderyakovlev.org. (kiru uakyty 30.05.2019).

Rossi, 1991 - Zhak Rossi. Spravochnik po GULAGU. [GULAG reference book] M.: Prosvet, 1991. Ch.1. 548 s. (in Rus)

Sərsembina, 2018 - SarsembinaK.K. Enbekpentyzetulagerleri mentyrmelerdegi ayelderzhagdayy (Stalindiksayasi-kugyn-syrginzhyldaryndagy) [Situationofwomeninlabourcampsandprisons] // Edu.e-history.kz. elektrondykzhurnal. - 2018. - №4. (16).

Sistema ispravitelno-trudovyh lagerey v SSSR, 1981 - Sistema ispravitelno-trudovyh lagerey $\vee$ SSSR 1923-1960: Spravochnik. [The system of labor camps in the USSR 1923-1960: Handbook.] M., 1981. 479 s. (in Rus)

Sobranie kodeksov RSFSR, 1928 - Sobranie kodeksov RSFSR redakcii $1926 \mathrm{~g}$. [Collection of codes of the RSFSR edition 1926] M.: Yur. izd. NKYu RSFSR, 1928. 1183 s. (in Rus)

Tasymbekov, 1993 - Tasymbekov A. Zhan dauysy. ALZhIR arhipelagy. [Cry of the soul, ALZHIRs archipelago] Almaty: Zhazushy, 1993. 223 b.

Uznicy «ALZhIRa, 2003 - Uznicy "ALZhIRa». Spisok zhenshchin - zaklyuchennyh Akmolinskogo i drugih otdeleniy Karlaga. [A Prisoner Of "Alzhir". List of women prisoners of Akmola and other departments of Karlag] M.: Zvenya, 2003. 567 s. (in Rus)

Frpaқtar ұmytpaydy, 2017 - «Urpaktar umytpaydy» = «Pomnyat Potomki» = «The descendants remember». Semey, 2017. 514 b.

CGA, 2-ser. der. film «ALZhIR» - Centralnyy Gosudarstvennyy arhiv kinofotodokumentov i zvukozapisi Respubliki Kazahstan [Central State archive of film and sound documents of the Republic of Kazakhstan] 